\title{
BCL-2 FAMILY PROTEINS IN DEVELOPMENT AND TREATMENT OF MALIGNANT DISEASES
}

\author{
Racay P., Jurecekova J., Stefanikova A., Klikova K., Hatok J., Dobrota D.
}

Institute of Medical Biochemistry, Jessenius Faculty of Medicine, Comenius University, Martin, Slovakia

\begin{abstract}
Proteins of Bcl-2 family are key regulators of mitochondrial pathway of apoptosis. Deregulation of apoptosis disrupts the complex and delicate balance between cell proliferation, survival and death and plays an important role in the development of malignant diseases. In addition to uncontrolled proliferation, alterations in apoptotic proteins are frequently associated with resistance of malignant cells to chemotherapy, leading to ineffective treatment with chemotherapy that primarily acts by apoptosis initiation. Despite the progress in combinatory and biologic therapy, response rates for treatment of different malignant diseases are not high enough. Therefore, new anticancer agents that selectively kill tumour cells and spare normal tissues are still urgently needed. Progress in biochemistry and cell biology leading to detailed dissection of cell signalling pathways allows development of new therapeutic strategies targeting different proteins involved in malignant transformation and uncontrolled proliferation of malignant cells. Emerging knowledge on molecular mechanisms of apoptosis deregulation in cancer development has revealed Bcl-2 family proteins as potential targets for drugs discovery. Structural analysis of these proteins together with studies of apoptosis mechanisms have outlined strategies for generation of new drugs, resulting in numerous novel chemical entities with mechanism-based activity. Many of the most logical targets for promoting apoptosis of malignant cells are technically challenging, involving often disruption of protein interactions or changes in gene expression, as opposed to traditional pharmaceutical approach that predominantly attacks enzymes. Understanding of the core components of the apoptotic machinery at the molecular and structural levels may lead to new era in cancer therapy where the intrinsic and acquired resistance of malignant cells to apoptosis can be pharmacologically reversed, reinstating natural pathways of cell suicide.
\end{abstract}

Key words: Bcl-2 family proteins, apoptosis, cancer therapy, chemoresistance

\section{INTRODUCTION}

Apoptosis is an evolutionarily conserved mechanism of cell death that is crucial for the development of multicellular organisms. Apoptosis is also critical for the maintenance of normal tissue homeostasis by the removal of damaged, unnecessary or potentially dangerous cells. Unlike necrosis, apoptosis is characterized by typical morphologic and biochemical features such as cell shrinkage, condensation of nuclear chromatin and cleavage of genomic DNA at internucleosomal sites, resulting in the generation of a characteristic pattern of DNA fragments [1]. Blebbing of the cell surface results in the release of membranebound apoptotic vesicles. Cells undergoing apoptosis are eliminated by macrophages or neighbouring cells without inflammation of surrounding tissue. The majority of molecular changes during apoptosis are caused by family of intracellular cysteine proteases, called caspases. Caspases synthesised as inactive zymogens are proteolytically processed to an active form following apoptotic stimulus [2]. Two groups of caspases are recognized according to their functions. Initiator caspases (caspases 2, 8, 9, 10) are capable of autocatalytic activation in response to different stimuli. Active initiator caspases are capable of proteolytic cleavage and consequent activation of effector caspases (caspases $3,6,7$ ) that can cleave various cellular substrates such as cytoskeletal proteins or proteins involved in signal transduction. Cleavage of target proteins is associated with cell collapse and induction cell death [3]. In addition, proteolytic degradation of inhibitor of caspase activated DNAse leads to intranucleosomal fragmentation of genomic DNA. There are two distinct pathways that lead

Address for correspondence:

Correspondence to: Peter Racay, PhD., Institute of Medical Biochemistry, Jessenius Faculty of Medicine, Comenius University, Malá Hora 4, 03601 Martin, Slovakia

Tel: +421-43-4131565, Fax: +421-43-4136760, E-mail: racay@jfmed.uniba.sk 
to apoptotic cell death: (1) the extrinsic or receptor pathway; and (2) the intrinsic or mitochondrial pathway [1,2].

The extrinsic pathway is initiated by the binding of extracellular ligands (e. g. members of tumour necrosis factor super family) to their receptors on plasma membrane, which induces formation of the death-inducing signalling complex (DISC) by binding to specific intracellular proteins characterised by presence of death domain [2]. DISC promotes activation of initiator caspase 8 and consequent activation of effector caspase 3. Degradation of substrate proteins by active caspase 3 culminates in apoptotic cell death.

The intrinsic pathway is usually initiated in response to intracellular stress, which include hypoxia, DNA damage, viral infection and activation of oncogenes. Proteins of Bcl-2 family are central regulators of mitochondrial pathway of apoptosis [4]. The BCL-2 (B-cell lymphoma gene-2) gene was first cloned from the breakpoint of the $t(14 ; 18)$ translocation in Bcell follicular lymphoma [5]. Its discovery has led to identification of a whole family of proteins that control commitment to apoptosis via mitochondrial pathway [4]. To date, 25 members of the Bcl-2 family have been identified. In addition to cytoplasm, these proteins are located predominantly in the outer mitochondrial membrane [2]. Proteins of the Bcl-2 family are related to each other due to their four conserved Bcl-2 homology (BH) domains and can be classified into three subfamilies based on structural and functional features [4].

The anti-apoptotic subfamily contains the Bcl-2, Bcl-xl, Bcl-w, Mcl-1, Blf1/A-1 and Bcl-B proteins, which suppress apoptosis and contain all four BH domains, designated 1-4. The 3-dimensional structures of anti-apoptotic Bcl-2 proteins reveal that each has a similar overall helical fold centered on a core hydrophobic helix with the BH1-3 domains arranged to expose a hydrophobic groove on the molecule. The integrity of this hydrophobic groove is required both for their pro-survival activity and for the binding of their pro-apoptotic partners.

Pro-apoptotic proteins, such as BAX, BAK, and BOK, contain BH 1-3 domains and are termed "multidomain proteins", whereas other pro-apoptotic proteins, such as BIM, BAD, BID, PUMA and Noxa contain only BH3 domain and are termed "BH3-only" proteins. The $\mathrm{BH} 3$ domain of pro-apoptotic proteins is the most important mediator of the interaction with anti-apoptotic proteins. In viable cells, the „multidomain“ pro-apoptotic proteins are present in the form of inactive monomers residing at the mitochondria (BAK), where are bound to anti-apoptotic proteins Bcl-xl or Mcl-1, or in the cytosol (BAX) [6]. In response to multiple types of stress, BAX translocates to mitochondria. Monomeric BAX and BAK undergo a conformational change leading to dimerisation and formation of oligomers during apoptosis. These changes occur at mitochondrial membranes and are promoted by local availability of selected BH3-only proteins (BIM, BID, and PUMA) [7]. Oligomerisation of BAX and BAK leads to pore formation in outer mitochondrial membrane followed by the release of cytochrome $\mathrm{c}$ and other pro-apoptotic proteins from mitochondria to cytosol, activation of initiator caspase 9 and consequent activation of caspase 3 and apoptosis initiation [4].

The „BH3-only“ proteins bind due to $\mathrm{BH} 3$ domain into the hydrophobic groove of antiapoptotic proteins inhibiting their anti-apoptotic function and indirectly activate BAX and/or BAK. The balance between pro- and anti-apoptotic members of Bcl-2 family expressed in outer mitochondrial membrane determines apoptosis initiation or cell survival. Disruption of this complex equilibrium may result in overinduction of apoptosis or by contrast in regression of apoptosis [8]. In addition to the regulation of cell cycle and DNA repair, p53 is an important regulator of mitochondrial apoptosis at the level of Bcl2 family proteins. It can initiate apoptosis by transcriptional activation of the expression of pro-apoptotic proteins (e.g. BAX, BAK, PUMA and Noxa) [9], as well as transcriptional repression of the expression of anti-apoptotic proteins of Bcl-2 family [10]. Transcriptionindependent pathway involves translocation of p53 to mitochondrial membrane and its direct binding to anti-apoptotic proteins (e.g. Bcl-xl); thereby inhibiting their anti-apoptotic function [11]. 


\section{DEREGULATION OF BCL-2 FAMILY PROTEINS IN MALIGNANT CELLS}

Deregulation of apoptosis plays an important role in the development of a variety of human pathologies, including autoimmune, neurodegenerative and malignant diseases [1]. The identification of the components of apoptotic pathways has enabled the detection of various biochemical defects present in malignant cells compared to their normal counterparts [12]. These defects contribute to the survival advantage of malignant clone over the normal cells and are also frequently associated with low response rate to standard chemotherapy and poor survival of patients [13]. Significant correlation between expression of some proteins of Bcl-2 family and sensitivity of cancer cell lines to more than 100 cytostatics was documented [14]. Dissection of molecular pathway of apoptosis has lead to the identification of many potential targets for the development of new drugs targeting anti-apoptotic molecules abnormally expressed or deregulated in malignant cells. Many of these drugs have potential to restore the sensitivity of malignant cells to apoptotic stimuli and some of them are under investigation at a clinical level [15]. Molecular mechanisms involved in deregulation of mitochondrial apoptosis in malignant cells include overexpression of antiapoptotic proteins and down-regulation or loss of function of pro-apoptotic proteins.

\section{OVEREXPRESSION OF ANTI-APOPTOTIC PROTEINS}

The overexpression of proto-oncogene BCL-2 was first identified in $70 \%$ of human follicular B-cell lymphomas due to $\mathrm{t}(14 ; 18)$ chromosomal translocation [5]. The same translocation, however with less frequency (28\%), was detected in diffuse large B-cell lymphomas

Table 1. Association of Bcl-2 Anti-apoptotic Family Members with Human Malignant Diseases

\begin{tabular}{|l|l|l|}
\hline Protein & Diagnosis & Reference \\
\hline \multirow{5}{*}{ Bcl-2 } & Neuroblastoma & 24 \\
\cline { 2 - 3 } & Small-cell lung carcinoma & 25 \\
\cline { 2 - 3 } & Acute and chronic lymphoid leukaemias & $19,20,26$ \\
\cline { 2 - 3 } & Acute myeloid leukaemia & 27 \\
\cline { 2 - 3 } & Breast adenocarcinoma & 28 \\
\hline \multirow{5}{*}{ Bcl-xl } & Prostate adenocarcinoma & 29 \\
\cline { 2 - 3 } & Lung adenocarcinoma & 30 \\
\cline { 2 - 3 } & Hepatocellular carcinoma & 31 \\
\cline { 2 - 3 } & Glioma & 32 \\
\cline { 2 - 3 } & Colorectal adenocarcinoma & 33 \\
\cline { 2 - 3 } & Acute lymphoblastic leukaemia & 34 \\
\cline { 2 - 3 } & Renal carcinoma & 35 \\
\hline Mcl-1 & B-cell non-Hodgkin lymphomas & 36 \\
\cline { 2 - 3 } & Anaplastic large cell lymphoma & 37 \\
\cline { 2 - 3 } & Multiple myeloma & 38 \\
\cline { 2 - 3 } & Melanoma & 40 \\
\hline \multirow{5}{*}{ Bcl-w } & Gastric adenocarcinoma & 41 \\
\cline { 2 - 3 } & Colorectal adenocarcinoma & \\
\hline
\end{tabular}


(DLBCL) [16]. This translocation places the BCL-2 gene into juxtaposition with powerful enhancer elements associated with immunoglobulin heavy chain locus, which results in elevated levels of Bcl-2 mRNA and protein [17]. In addition to t $(14 ; 18)$ chromosomal translocation, $\mathrm{t}(2 ; 18)$ and $\mathrm{t}(18 ; 22)$ translocations that involve Bcl-2 and either IG kappa or lambda genes have been observed in some rare cases of B cell malignancies. The molecular analysis revealed that these translocations juxtaposed the BCL-2 and immunoglobulin light-chain (IGL) genes [18] and is cause of Bcl-2 overexpression in approximately $10 \%$ of cases of chronic lymphoblastic leukaemia (CLL) [19]. Bcl-2 was found to be overexpressed in all investigated cases of CLL [20]. Although hypomethylation of the bcl-2 gene did not necessarily correlate with the relative levels of Bcl-2 protein present in the B-CLL cells [20], this epigenetic event represents additional mechanisms for regulating Bcl-2 expression in cancer cells. Increased expression of Bcl-2 protein was also described in 31\% of DLBCL due to $B C L-2$ gene amplification which was independent from $\mathrm{t}(14 ; 18)$ chromosomal translocation [21]. Overexpression of the apoptotic protein Bcl-2 provides a block in apoptosis that can be frequently observed also in other types of cancers (Table 1). The up-regulation of Bcl-2 can be used as prognostic marker in some cancer types while it does not correlate with disease progression in other types [22]. In the most cases, overexpression of Bcl-2 is associated with resistance to chemotherapy. For example, high level of Bcl-2 in acute myeloid leukaemia (AML) is associated with poor remission outcome and patient survival [23].

Alternative splicing of $B C L-X$ gene gives two variants, long variant $\mathrm{Bcl}-\mathrm{xl}$ and short variant $\mathrm{Bcl}-\mathrm{xs}$ that are translated to proteins with opposite functions. Bcl-xl is the most potent anti-apoptotic protein of Bcl-2 family that is often up-regulated in malignant cells due to replacement of wild type exon IA of $B C L-X$ gene with exon IB. The promoter found upstream of exon IB is 300-fold more potent that "wild" type promoter [42]. Bcl-xl is also upregulated in many types of malignacies (Table 1). On the other hand, association of decreased level of mRNA of anti-apoptotic Bcl-xs with shorter disease free and overall survival indicates important association of $B C L-X$ gene products with chemotherapy induced cell death [43].

In addition to Bcl-2 and Bcl-xl, increased expression of other anti-apoptotic proteins of Bcl-2 family (e. g. Mcl-1, and Bcl-w) occurs in significant subsets of common types of malignant diseases (Table 1) and is generally correlated with poor response. However, the exact cause of overexpression of these proteins is not yet fully elucidated.

\section{DOWN-REGULATION OR LOSS OF FUNCTION OF PRO-APOPTOTIC PROTEINS}

Down-regulation of BAX, the main pro-apoptotic pore forming protein of Bcl-2 family, is often observed in some solid tumours. In the most cases, the reduced level of BAX protein is accompanied by mutations in the P53 gene. According to its function in cell death, P53 gene is frequently mutated in solid tumours [44], leading to expression of inactive p53 protein which cannot activate transcription of $B A X$ gene. Frameshift mutations of $B A X$ gene have been detected in T cells of acute lymphoblastic leukaemia (ALL) [45] and endometrium [46]. In all cases of gastrointestinal cancers, there are two characteristic missense mutations of BAX gene in codon 169 (Thr $\rightarrow$ Ala or Thr $\rightarrow$ Met). These mutations are functional and therefore, they inhibit the pro-apoptotic activity of the protein and contribute to carcinogenesis [47]. Finally, Rampino et al. [48] found that more than 50\% of human matrix metalloproteinase positive (MMP+) colon adenocarcinomas had frameshift mutations in the third exon, spanning codons 38 to 41 . These results suggest that inactivating $B A X$ gene mutations are selected during the progression of colorectal MMP+ tumours and that the wild type BAX protein plays a suppressor role in a p53-independent pathway for colorectal carcinogenesis.

Reduced levels of BAK, another pore forming protein, were detected in gastric tumours [49] and colorectal adenocarcinomas [33]. This down-regulation may be explained by the presence of missense mutations in the $B A K$ gene [50]. Six missense mutations were found by analysis of the $B A K$ gene in the carcinomas of uterine cervix, while no mutations were 
detected in normal cervical tissues [51]. BAK mutations were observed more frequently in the advanced stage, at which mutated cancer tissues were resistant to radiotherapy [51].

\section{THERAPY OF MALIGNANT DISEASES TARGETING THE BCL-2 FAMILY PROTEINS}

The fact that high expression of anti-apoptotic proteins of Bcl-2 family may confer resistance to chemo- or radiotherapy initiated the effort in developing strategies that overcome the cytoprotective effect of these proteins. Less effort has been made in search of strategies restoring the activity of pro-apoptotic proteins. Attempts to overcome the cytoprotective effects of anti-apoptotic proteins include 3 strategies: (1) shutting off gene expression; (2) inducing mRNA degradation; and (3) direct attack of the proteins with small-molecule inhibitors [52].

\section{Drugs regulating gene expression}

Several types of drugs regulating the expression of anti-apoptotic Bcl-2 family genes were found. Some synthetic retinoids reduce levels of Bcl-2 or Bcl-xl mRNA in malignant cells (e. g. fenretinide) [52]. Fenretinide has shown promising anticancer activity in preclinical studies, but its limited oral bioavailability has hindered clinical assessment.

Also inhibitors of histone deacetylases (HDACs), chromatin-modifying enzymes, have the ability to reduce the expression of $B C L-2, B C L-X$ or $M C L-1$ at transcriptional level. For example, sodium butyrate, inhibitor of class I HDAC, induces apoptotic cell death accompanied by up-regulation of pro-apoptotic BAX and down-regulation of anti-apoptotic Bcl-2 and Bclxl [53]. Clinical trials of HDAC inhibitors are progressing, with hints of activity documented for lymphoma and some solid tumours [54]. The use of valproic acid that acts also as a class I HDAC inhibitor has shown promising results in patients with AML and myelodysplastic syndromes [55].

\section{Drugs attacking $\mathrm{mRNA}$}

Antisense oligonucleotides are short single stranded synthetic deoxyribonucleotides that complement and bind specific coding regions on mRNA, forming DNA/RNA hybrids which are subsequently degraded. Thus, degradation of mRNA prevents translation of the targeted protein. This approach is highly specific since any DNA sequence longer than 17 nucleotides occurs only once within human genome. Preclinical studies have demonstrated that oblimersen sodium (Genasense; G3139), an 18-mer phosphorotioated oligodeoxynucleotide antisense designed to bind the first six codons of human Bcl-2 open reading frame, downregulates expression of its target [56]. The feasibility of this approach in vivo was investigated in several phase II/III trials of oblimersen alone or in combination with other therapy in both solid tumours and haematological malignancies [52]. In a recent phase III study, oblimersen combined with fludarabine/cyclophosphamide was shown to prolong survival of a subset of patients with refractory or relapsed CLL [57]. Oblimersen also holds promise for the treatment of metastatic melanoma [58].

\section{Small-molecule inhibitors of the Bcl-2 family proteins}

Intensive research using computational modeling has led to discovery of structures of new small molecules that could potentially promote death of cancer cells. Designed molecules mimic the function of BH3-only pro-apoptotic proteins, destroying cancer cells by inhibiting activity of anti-apoptotic proteins and specifically targeting pathways that allow survival of cancer cells [59]. The attempt to target the protein-protein interaction site between antiapoptotic Bcl-2 proteins and BAX or BAK has resulted in the generation of ABT-737, which binds with high affinity $(\mathrm{Ki} \leq 1 \mathrm{nM})$ to $\mathrm{Bcl}-2$, Bcl-xl and $\mathrm{Bcl}-\mathrm{w}$, but not to the less homologous proteins Bcl-B, Mcl-1 and A1 (Ki >1 $\mu \mathrm{M})$ [60]. ABT-737 binds directly into the hydrophobic groove in the structure of anti-apoptotic proteins. Thus, ABT-737 inhibits anti-apoptotic Bcl-2 family proteins, but does not directly activate the pro-apoptotic proteins 
BAX and BAK. ABT-737 is an effective single agent in a panel of different malignancies, especially in those that critically depend on anti-apoptotic Bcl-2 proteins for survival [60, 61]. Using of ABT-737 as a therapeutic agent is obstructed by its poor pharmaceutical properties. This compound is not orally bioavailable and has low solubility in water. The secondgeneration inhibitor ABT-263, that is orally bioavailable, is currently evaluated in phase I/II trials for lymphoma and CLL [62] as well as small cell lung carcinoma [63]. However, inhibition of Bcl-2, Bcl-xl and Bcl-w by ABT-263 has only moderate effects on survival of different types of malignant cells and additional inhibition of Mcl-1 is required to activate cell death [60, 62]. Therefore ABT-263 may have limited clinical potential for the treatment of glioma and other solid tumours [64]. However, ABT-263 and related compounds display synergism with chemo- and radiotherapy, significantly reducing the median effective concentration $\left(\mathrm{EC}_{50}\right)$ value for cytotoxicity of the chemotherapeutic in a variety of cancer cell lines [60].

Obatoclax (GX15-070) mesylate is a molecule that can also supplement the activity of ABT-263. Although obatoclax mesylate has a lower affinity than ABT-263 for Bcl-2, Bcl-xl and Bcl-w, it can successfully prevent Mcl-1/BAK binding [65]. Phase I studies in different malignancies demonstrated evidence for single-agent activity and was well tolerated. Clinical response to obatoclax mesylate was observed in patients with refractory leukaemia [66], with CLL [57] and lymphoma or advanced solid tumours [67]. Its safety profile makes it an attractive candidate for its combinatorial use with traditional chemotherapy [68]. Promising results were obtained during phase I trials using obatoclax mesylate in combination with topotecan in patients with relapsed small cell lung carcinoma [69].

In addition to synthetic compounds, natural substances are tested for treatment of different malignant diseases. Gossypol is a natural polyphenolic compound and BH3 mimetic derived from cottonseeds, which possesses pro-apoptotic effects in various in vivo and in vitro models [70]. Similar to obatoclax, gossypol acts as a pan-Bcl-2 inhibitor and can inactivate Bcl-2, Bcl-xl, Mcl-1 and Bcl-w. There are two enantiomers of gossypol, (+)-gossypol and (-)-gossypol. The latter being more potent tumour growth inhibitor, (-)-gossypol (AT101), has shown single-agent activity in various types of malignant diseases. Although gastrointestinal toxicity is considerable dose limiting factor [52], its potential impact for cancer therapy is currently investigated in phase I/II clinical trials. As a single agent AT-101 is tested for treatment of prostate cancer [71] and gliomas [64]. AT-101 combined with topotecan at a reduced dose is currently investigated in phase I/II clinical trials for treatment of relapsed and refractory small cell lung carcinoma [72].

A combination of drugs targeting several anti-apoptotic proteins may be necessary to overcome resistance to apoptosis in some cancers. For such reason, recent research is directed not only at investigation of clinical effects of already discovered inhibitors, but also at identification of new small molecules that could make stable complexes simultaneously with Bcl-2, Bcl-xl and Mcl-1. A few small molecules were obtained by computer-based modification of known molecules. Usefulness of the new designed molecules for anticancer drug development is waiting for determination [59].

\section{CONCLUSIONS}

The development and progression of the malignant diseases invariably involve deregulation of apoptosis. Despite major efforts during the past 40 years, limited improvements in response rates and overall survival have been made. The current primary treatment for malignant diseases is chemotherapy inducing cell death by apoptosis mainly mediated through the mitochondrial pathway. The progress made in understanding of the central role of apoptosis deregulation in the development of malignant diseases and chemoresistance has launched the academic community, as well as the pharmaceutical and biotechnology industry into a search to indentify new compounds for the treatment of malignant diseases. Targeted therapies that are designated to induce apoptosis in malignant cells are currently 
the most promising anticancer strategies. These strategies are aimed at targeting and killing the malignant cells specifically with no or limited collateral damage to normal cells. Finally, further elucidation of the molecular apoptotic machinery as well as its defects in malignant diseases lays the basis for developing new drugs able to trigger apoptosis of malignant cells, and therefore to improve survival of cancer patients.

\section{REFERENCES}

1. Hotchkiss RS, Strasser A, McDunn JE, Swanson PE. Cell death. N Engl J Med 2009; 361(16): 1570-83.

2. Jin Z, El-Deiry WS. Overview of cell death signalling pathways. Cancer Biol Ther 2005; 4(2): 139-163.

3. Degterev A, Boyce M, Yuan J. A decade of caspases. Oncogene 2003; 22(53): 8543-67.

4. Youle RJ, Strasser A. The BCL-2 family proteins: opposite activities that mediate cell death. Nat. Rev. Mol. Cell Biol 2008; 9(1): 47-59.

5. Tsujimoto Y, Cossman J, Jaffe E, Croce CM. Involvement of the bcl-2 gene in human follicular lymphoma. Science 1985; 228(4706): 1440-3.

6. Willis SN, Chen L, Dewson G, Wei A, Naik E, Fletcher JI, Adams JM, Huang DC. Proapoptotic Bak is sequestered by Mcl-1 and Bcl-xL, but not Bcl-2, until displaced by BH3-only proteins. Genes Dev 2005; 19(11): 1294-305.

7. Willis SN, Fletcher JI, Kaufmann T, van Delft MF, Chen L, Czabotar PE, Ierino H, Lee EF, Fairlie WD, Bouillet P, Strasser A, Kluck RM, Adams JM, Huang DC. Apoptosis initiated when BH3 ligands engage multiple Bcl-2 homologs, not Bax or Bak. Science 2007; 315(5813): 856-9.

8. Kim H, Rafiuddin-Shah M, Tu HC, Jeffers JR, Zambetti GP, Hsieh J, Cheng E. Hierarchical regulation of mitochondrion-dependent apoptosis by BCL-2 subfamilies. Nat Cell Biol 2006; 8(12): 1348-58.

9. Sax JK, El Deiry WS. p53 downstream targets and chemosensitivity. Cell Death Differ 2003; 10(4): 413-17.

10. Wu Y, Mehew JW, Heckman CA, Arcinas M, Boxer LM. Negative regulation of bcl-2 expression by p53 in hematopoietic cells. Oncogene 2001; 20(2): 240-51.

11. Chipuk JE, Kuwana T, Bouchier-Hayes L, Droin NM, Schuler M, Green DR. Direct activation of Bax by p53 mediates mitochondrial membrane permeabilization and apoptosis. Science 2004; 303(60): 1010-4.

12. Cotter TG. Apoptosis and cancer: the genesis of a research field. Nat Rev Cancer. 2009; 9(7): 501-7.

13. Wilson TR, Johnston PG, Longley DB. Anti-apoptotic mechanisms of drug resistance in cancer. Curr Cancer Drug Targets. 2009; 9(3): 307-19.

14. Amundson SA, Myers TG, Scudiero D, Kitada S, Reed JC, Fornace AJ. An informatics approach identifying markers of chemosensitivity in human cancer cell lines. Cancer Res 2000; 60(21): 6101-10.

15. Hockenbery DM. Targeting mitochondria for cancer therapy. Environ Mol Mutagen. 2010; 51(5): 476-89.

16. Weiss LM, Warnke RA, Sklar J, Cleary ML. Molecular analysis of the $t(14 ; 18)$ chromosomal translocation in malignant lymphomas. N Engl J Med. 1987; 317(19): 1185-1189.

17. Cleary ML, Smith SD, Sklar J. Cloning and structural analysis of cDNAs for bcl-2 and a hybrid bcl2 /immunoglobulin transcript resulting from the $\mathrm{t}(14 ; 18)$ translocation. Cell 1986; 47(1): 19-28.

18. Bertheas MF, Bachy M, Magaud JP, Rimokh R, Vasselon C, Berger F, Oriol PC, Jaubert J, Reynaud J, Brizard $\mathrm{CP}$, et al. $\mathrm{t}(2 ; 18)$ and $\mathrm{t}(18 ; 22)$ variant chromosomal translocations in B cell malignancies. Leuk Lymphoma. 1992; 8(3): 197-200.

19. Adachi M, Tefferi A, Greipp PR, Kipps TJ, Tsujimoto Y. Preferential linkage of bcl-2 to immunoglobulin light chain gene in chronic lymphocytic leukemia. J Exp Med 1990; 171(2): 559-64.

20. Hanada M, Delia D, Aiello A, Stadtmauer E, Reed JC. bcl-2 gene hypomethylation and high-level expression in B-cell chronic lymphocytic leukemia. Blood. 1993; 82(6): 1820-1828.

21. Monni O, Joensuu H, Franssila K, Klefstrom J, Alitalo K, Knuutila S. BCL2 overexpression associated with chromosomal amplification in diffuse large B-cell lymphoma. Blood. 1997; 90(3): 1168-1174.

22. Thomadaki H, Scorilas A. BCL2 family of apoptosis-related genes: functions and clinical implications in cancer. Crit Rev Clin Lab Sci 2006; 43(1): 1-67.

23. Tothova E, Fricova M, Stecova N, Kafkova A, Elbertova A. High expression of Bcl-2 protein in acute myeloid leukemia cells is associated with poor response to chemotherapy. Neoplasma 2002; 49(3): 141-44.

24. Castle VP, Heidelberger KP, Bromberg J, Ou X, Dole M, Nuñez G. Expression of the apoptosis-suppressing protein bcl-2, in neuroblastoma is associated with unfavourable histology and N-myc amplification. Am $J$ Pathol 1993; 143(6): 1543-50.

25. Jiang SX, Sato Y, Kuwao S, Kameya T. Expression of bcl-2 oncogene protein is prevalent in small cell lung carcinomas. J Pathol 1995; 177(2): 135-8.

26. Molica S, Mannella A, Dattilo A, Levato D, Iuliano F, Peta A, Consarino C, Magro S. Differential expression of BCL-2 oncoprotein and Fas antigen on normal peripheral blood and leukemic bone marrow cells. A flow cytometric analysis. Haematologica 1996; 81(4): 302-9.

27. Klobusická M, Kusenda J, Babusikova O. Expression of p53 and bcl-2 proteins in acute leukemias: an immunocytochemical study. Neoplasma 2001; 48(6): 489-95. 
28. Doglioni C, Dei Tos AP, Laurino L, Chiarelli C, Barbareschi M, Viale G. The prevalence of BCL-2 immunoreactivity in breast carcinomas and its clinicopathological correlates, with particular reference to oestrogen receptor status. Virchows Arch 1994; 424(1): 47-51.

29. Krajewska M, Krajewski S, Epstein JI, Shabaik A, Sauvageot J, Song K, Kitada S, Reed JC. Immunohistochemical analysis of bcl-2, bax, bcl-X, and mcl-1 expression in prostate cancers. Am J Pathol 1996; 148(5): 1567-76.

30. Singhal S, Amin KM, Kruklitis R, Marshall MB, Kucharczuk JC, DeLong P, Litzky LA, Kaiser LR, Albelda SM. Differentially expressed apoptotic genes in early stage lung adenocarcinoma predicted by expression profiling. Cancer Biol Ther 2003; 2(5): 566-71.

31. Watanabe J, Kushihata F, Honda K, Mominoki K, Matsuda S, Kobayashi N. BclxL overexpression in human hepatocellular carcinoma. Int J Oncol 2002; 21(3): 515-9.

32. Krajewski S, Krajewska M, Ehrmann J, Sikorska M, Lach B, Chatten J, Reed JC. Immunohistochemical analysis of Bcl-2, Bcl-X, Mcl-1, and Bax in tumors of central and peripheral nervous system origin. Am J Pathol 1997; 150(3): 805-14.

33. Krajewska M, Moss SF, Krajewski S, Song K, Holt PR, Reed JC. Elevated expression of Bcl-X and reduced Bak in primary colorectal adenocarcinomas. Cancer Res 1996; 56(10): 2422-7.

34. Račay P, Hatok J, Hudeček J, Chudej J, Jurečeková J, Dobrota D. Transcription of genes of p53-dependent apoptosis in acute leukaemia. Int J Mol Med 2008; 22(6): 833-9.

35. Gobé G, Rubin M, Williams G, Sawczuk I, Buttyan R. Apoptosis and expression of Bcl-2, Bcl-XL, and Bax in renal cell carcinomas. Cancer Invest 2002; 20(3): 324-32.

36. Cho-Vega JH, Rassidakis GZ, Admirand JH, Oyarzo M, Ramalingam P, Paraguya A, McDonnell TJ, Amin HM, Medeiros LJ. MCL-1 expression in B-cell non-Hodgkin's lymphomas. Hum Pathol 2004; 35(9): $1095-100$.

37. Rassidakis GZ, Lai R, McDonnell TJ, Cabanillas F, Sarris AH, Medeiros LJ. Overexpression of Mcl-1 in anaplastic large cell lymphoma cell lines and tumors. Am J Pathol 2002; 160(6): 2309-10.

38. Wuillème-Toumi S, Robillard N, Gomez P, Moreau P, Le Gouill S, Avet-Loiseau H, Harousseau JL, Amiot M, Bataille R. Mcl-1 is overexpressed in multiple myeloma and associated with relapse and shorter survival. Leukemia 2005; 19(7): 1248-52.

39. Wong RP, Khosravi S, Martinka M, Li G. Myeloid leukemia-1 expression in benign and malignant melanocytic lesions. Oncol Rep 2008; 19(4): 933-7.

40. Lee HW, Lee SS, Lee SJ, Um HD. Bcl-w is expressed in a majority of infiltrative gastric adenocarcinomas and suppresses the cancer cell death by blocking stress-activated protein kinase/c-Jun NH2-terminal kinase activation. Cancer Res 2003; 63(5): 1093-100.

41. Wilson JW, Nostro MC, Balzi M, Faraoni P, Cianchi F, Becciolini A, Potten CS. Bcl-w expression in colorectal adenocarcinoma. Br J Cancer 2000; 82(1): 178-85.

42. MacCarthy-Morrogh L, Wood L, Brimmell M, Johnson PW, Packham G. Identification of a novel human BCLX promoter and exon. Oncogene 2000; 19(48): 5534-8.

43. Yamaguchi H, Inokuchi K and Dan K: The study for loss of bcl-xs expression as a prognostic factor in acute myeloid leukemia. Leuk Res 2002; 26(12): 1119-23.

44. Soussi T. p53 alterations in human cancers: more questions than answers. Oncogene 2007; 26(15): 2145-56.

45. Inoue K, KohnoT, Takakura S, Hayashi Y, Mizoguchi H, Yokota J. Frequent microsatellite instability and BAX mutations in T cell acute lymphoblastic leukemia cell lines. Leuk Res 2000; 24(3): $255-62$.

46. Marone M, Ferrandina G, Macchia G, Mozzetti S, de Pasqua A, Benedetti-Panici P, Mancuso S, Scambia G. Bcl2, Bax, Bcl-x(L) and Bcl-x(S) expression in neoplastic and normal endometrium. Oncology 2000; 58(2): 161-8.

47. Gil J, Yamamoto H, Zapata JM, Reed JC, Perucho M. Impairment of the proapoptotic activity of Bax by missense mutations found in gastrointestinal cancers. Cancer Res 1999; 59(9): $2034-7$.

48. Rampino, N., Yamamoto, H., Ionov, Y., Li, Y., Sawai, H., Reed, J. C., Perucho, M. Somatic frameshift mutations in the BAX gene in colon cancers of the microsatellite mutator phenotype. Science 1997; 275(5302): 967-9.

49. Krajewska M, Fenoglio-Preiser CM, Krajewski S, Song K, Macdonald JS, Stemmerman G, Reed JC. Immunohistochemical analysis of Bcl-2 family proteins in adenocarcinomas of the stomach. Am J Pathol 1996; 149(5): 1449-57.

50. Kondo S, Shinomura Y, Miyazaki Y, Kiyohara T, Tsutsui S, Kitamura S, Nagasawa Y, Nakahara M, Kanayama S, Matsuzawa Y. Mutations of the bak gene in human gastric and colorectal cancers. Cancer Res 2000; 60(16): 4328-30.

51. Wani KM, Huilgol NG, Hongyo T, Shah K, Chatterjee N, Nair CK, Nomura T. Genetic alterations in the coding region of the bak gene in uterine cervical carcinoma. Br J Cancer 2003; 88(10): 1584-6.

52. Kang MH, Reynolds P. Bcl-2 inhibitors: targeting mitochondrial apoptotic pathways in cancer therapy. Clin Cancer Res 2009; 15(4): 1126-32.

53. Choi YH. Apoptosis of U937 human leukemic cells by sodium butyrate is associated with inhibition of telomerase activity. Int J Oncol 2006; 29(5): 1207-13.

54. Kelly TK, De Carvalho DD, Jones PA. Epigenetic modifications as therapeutic targets. Nat Biotechnol. 2010; 28(10): 1069-78.

55. Kuendgen A, Gattermann N. Valproic acid for the treatment of myeloid malignancies. Cancer 2007; 110(5): 94354.

56. Klasa RJ, Gillum AM, Klem RE, Frankel SR. Oblimersen Bcl-2 antisense: Facilitating apoptosis in cancer treatment. Antisense Nucleic Acid Drug Dev 2002; 12(3): 193-213. 
57. O’Brien SM, Claxton DF, Crump M, Faderl S, Kipps T, Keating MJ, Viallet J, Cheson BD. Phase I study of obatoclax mesylate (GX15-070), a small molecule pan-Bcl-2 family antagonist, in patients with advanced chronic chronic lymphocytic leukemia. Blood 2009; 113(2): 299-305.

58. Di Cresce C, Koropatnick J. Antisense treatment in human prostate cancer and melanoma. Curr Cancer Drug Targets. 2010; 10(6): 555-65.

59. Dalafave DS, Prisco G Inhibition of antiapoptotic BCL-XL, BCL-2 and MCL-1 proteins by small molecule mimetics. Cancer Inform. 2010; 9: 169-77.

60. Oltersdorf T, Elmore SW, Shoemaker AR, Armstrong RC, Augeri DJ, Belli BA, Bruncko M, Deckwerth TL, Dinges J, Hajduk PJ, Joseph MK, Kitada S, Korsmeyer J, Kunzer AR, Letai A, Li Ch, Mitten MJ, Nettesheim DG, Ng S, Nimmer PM, O’Connor JM, Oleksijew A, Petros AM, Reed JC, Shen W, Tahir SK, Thompson CB, Tomaselli KJ, Wang B, Wendt MD, Zhang H, Fesik SW, Rosenberg SH. An inhibitor of Bcl-2 family proteins induces regression of solid tumours. Nature 2005; 435(7042): 677-81.

61. Vogler M, Dinsdale D, Sun XM, Young KW, Butterworth M, Nicotera P, Dyer MJS, Cohen GM A novel paradigm for rapid ABT-737-induced apoptosis involving outer mitochondrial membrane rupture in primary leukemia and lymphoma cells. Cell Death Differ 2008; 15(5), 820-30.

62. Tse Ch, Shoemaker AR, Adickes J, Anderson MG, Chen J, Jin S, Johnson F, Marsh K C, Mitten MJ, Nimmer P, Roberts L, Tahir SK, Xiao Y, Yang X, Zhang H, Fesik S, Rosenberg SH, Elmore SW ABT-263: a potent and orally bioavailable Bcl-2 family inhibitor. Cancer Res 2008; 68(9): 3421-8.

63. Gandhi L, Camidge DR, Ribeiro de Oliveira M, Bonomi P, Gandara D, Khaira D, Hann CL, McKeegan EM, Litvinovich E, Hemken PM, Dive C, Enschede SH, Nolan C, Chiu YL, Busman T, Xiong H, Krivoshik AP, Humerickhouse R, Shapiro GI, Rudin CM. Phase I study of Navitoclax (ABT-263), a novel Bcl-2 family inhibitor, in patients with small-cell lung cancer and other solid tumors. J Clin Oncol 2011; 29(7): 909-16.

64. Kögel D, Fulda S, Mittelbronn M. Therapeutic exploitation of apoptosis and autophagy for glioblastoma. Anticancer Agents Med Chem 2010; 10(6): 438-49.

65. Nguyen M, Marcellus RC, Roulston A, Watson M, Serfass L, Murthy Madiraju SR, Goulet D, Viallet J, Bélec L, Billot X, Acoca S, Purisima E, Wiegmans A, Cluse L, Johnstone RW, Beauparlant P, Shore GC. Small molecule obatoclax (GX 15-070) antagonizes MCL-1 and overcomes MCL-1-mediated resistance to apoptosis. Proc Natl Acad Sci USA 2007; 104(49), 19512-7.

66. Schimmer AD, O’Brien S, Kantarjian H, Brandwein J, Cheson BD, Minden MD, Yee K, Ravandi F, Giles F, Schuh A, Gupta V, Andreeff M, Koller C., Chang H, Kamel-Reid S, Berger M, Viallet J, Borthakur G. A phase I study of the pan Bcl-2 family inhibitor obatoclax mesylate in patients with advances hematologic malignancies. Clin Cancer Res 2008; 14(24), 8295-301.

67. Hwang JJ, Kuruvilla J, Mendelson D, Pishvaian MJ, Deeken JF, Siu LL, Berger MS, Viallet J, Marshall JL. Phase I dose finding studies of obatoclax (GX15-070), a small molecule pan-BCL-2 family antagonist, in patients with advanced solid tumors or lymphoma. Clin Cancer Res 2010; 16(15): 4038-45.

68. Konopleva M, Watt J, Contractor R, Tsao T, Harris D, Estrov Z, Bornmann W, Kantarjian H, Viallet J, Samudio I, Andreeff M. Mechanisms of antileukemic activity of the novel Bcl-2 homology domain-3 mimetic GX15-070 (obatoclax). Cancer Res 2008; 68(9): 3413-20.

69. Paik PK, Rudin CM, Brown A, Rizvi NA, Takebe N, Travis W, James L, Ginsberg MS, Juergens R, Markus S, Tyson L, Subzwari S, Kris MG, Krug LM. A phase I study of obatoclax mesylate, a Bcl-2 antagonist, plus topotecan in solid tumor malignancies. Cancer Chemother Pharmacol. 2010; 66(6): 1079-85.

70. Oliver CL, Bauer JA, Wolker KG, Ubell ML, Narayan A. In vitro effect of the BH3 mimetic, (-)-gossypol, on head and neck squamous cell carcinoma cells. Clin Cancer Res 2004; 10(22): 7757-63.

71. Liu G, Kelly WK, Wilding G, Leopold L, Brill K, Somer B. An open-label, multicenter, phase I/II study of singleagent AT-101 in men with castrate-resistant prostate cancer. Clin Cancer Res 2009; 15(9): 3172-6.

72. Heist RS, Fain J, Chinnasami B, Khan W, Molina JR, Sequist LV, Temel JS,Fidias P, Brainerd V, Leopold L, Lynch TJ. Phase I/II study of AT-101 with topotecan in relapsed and refractory small cell lung cancer. J Thorac Oncol 2010; 5(10): 1637-43.

Acknowledgment. This work was supported by project „CREATING A NEW DIAGNOSTIC ALGORITHM FOR SELECTED CANCER DISEASES“ co-financed from EU sources and European Regional Development Fund.

Received: July, 22, 2011

Accepted: November, 7, 2011 